\title{
The SIS limits and related proglacial events in the Severnaya Dvina basin, northwestern Russia: review and new data
}

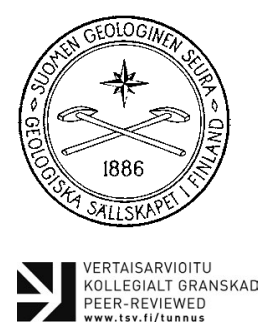

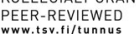

\author{
Nataliya E. Zaretskaya ${ }^{\mathrm{I}^{*}}$, Andrei V. Panin ${ }^{2,3}$ and Natalia V. \\ KARPUKHINA $^{2}$ \\ ${ }^{1}$ Geological Institute of RAS, Pyzhesky per. 7, Moscow, 119017, RUSSIA \\ ${ }^{2}$ Institute of Geography of RAS, Staromonetny per. 29, Moscow, 119017, RUSSIA \\ ${ }^{3}$ Lomonsov Moscow State University, Vorobiovy Gory 1, Moscow, 119991, RUSSIA
}

Keywords: Late Glacial Maximum, Scandinavian Ice Sheet, Severnaya Dvina River basin, proglacial lake, spillways

*Corresponding author (e-mail: n_zaretskaya@inbox.ru)

Editorial handling: Pertti Sarala (pertti.sarala@gtk.fi) 


\section{Introduction}

The history of the southeastern sector of the Scandinavian Ice Sheet (SIS) during the Last Glacial Maximum (LGM) and its subsequent retreat has two open questions which are still unsolved despite the decades of years of investigations and many efforts of different research groups, especially in the Severnaya Dvina (SD) basin.

The basic question is the position of the SIS boundary at LGM, which continues to "migrate" widely in this area, unlike that in the north of the Russian Plain (Mezen' and Pechora basins) where the LGM ice limits were accepted by most workers after the results of the QUEEN project (Svendsen et al., 2004). The second question is closely linked to the first one: the last SIS advance was accompanied by damming of rivers and the formation of proglacial lakes in the valleys of Severnaya Dvina and Vaga and their tributaries. Meanwhile, many questions concerning lake history, dimensions, drainage and chronology are far from being resolved. Therefore in 2017 we started new projects aimed to reconstruct the Weichselian history of the SD basin, clarify the position of SIS limits within it and on adjacent territories, and find traces of proglacial lakes and their overflows.

In this paper we present our recent results obtained between 2017 and early 2018 in the valley of Vychegda - the largest right tributary of $\mathrm{SD}$, on a background of analysis of evolution and contemporary state of views on the southeastern LGM ice sheet limits, adjacent proglacial lakes and their water overflow.

\section{Regional setting}

The southeastern flank of the last Scandinavian glaciation was expanding on the territory of the modern Arkhangelsk region and, possibly, the Komi Republic of Russia, overlapping the White Sea and part of the catchment area of the Severnaya Dvina river. The $\mathrm{SD}$ basin is located within a vast flat plain inclined to the north, and only its northeastern edge is captured by the Timan Ridge. The SD basin stretches from the southeast to the northwest, and includes the Severnaya Dvina river and its large tributaries - Vychegda (the largest right tributary), Sukhona and Vaga (the largest left tributaries) (Fig. 1). Quaternary deposits here have a thickness of $20 \mathrm{~m}$ or more and are underlain by bedrocks of the late Paleozoic and Mesozoic age which are exposed inside many river valleys. The most part of the Quaternary sediments are of glacial, fluvioglacial, fluvial, aeolian and palustral origin.

During the Middle and Late Pleistocene the territory of the basin was covered by two ice sheets - Moscow (Saalian, or Vychegodsky according to the local stratigraphy of northern Russia) and Late Valdai (LGM, Late Weichselian, or Polarny) (Andreicheva et al., 2015). The Moscow glaciation, the last one that completely covered the whole SD basin, is correlated with MIS 6 (Velichko et al., 2011), i.e. the period 190-130 ka BP (Lisiecki \& Raymo, 2005; Gibbard \& Cohen, 2008). Its sediments are represented by diamicton (loamy clay) of a reddish-brown color, turning into dark gray, with a clastic material content from 1-3 to 5-8\%, with high content of local sedimentary rocks (up to $95 \%$ ) - limestones, dolomites, flintstones etc.; therefore the diamicton composition is more carbonaceous (Ostanin et al., 1979). The number of Scandinavian rock clasts does not exceed 11-35\% (Atlasov et al., 1978).

The LGM deposits are also represented by diamicton, but the Scandinavian magmatic and metamorphic rocks - quartz and quartzites - are absolutely predominant (Ostanin et al., 1979). The position of the maximum advancement of the last glaciation is discussed in this article.

On the interfluves of the SD basin, glacial and fluvio-glacial landscapes predominate with some participation of aeolian forms. In the east of the basin, vast sandur plains are dominant. An ancient partly buried valley (the so called Keltma trough) of submeridional direction connecting the Vychegda basin with the Kama-Volga basin is clearly traced across the Severnye Uvaly Upland (Fig. 1); now it is occupied by the rivers Northern Keltma 


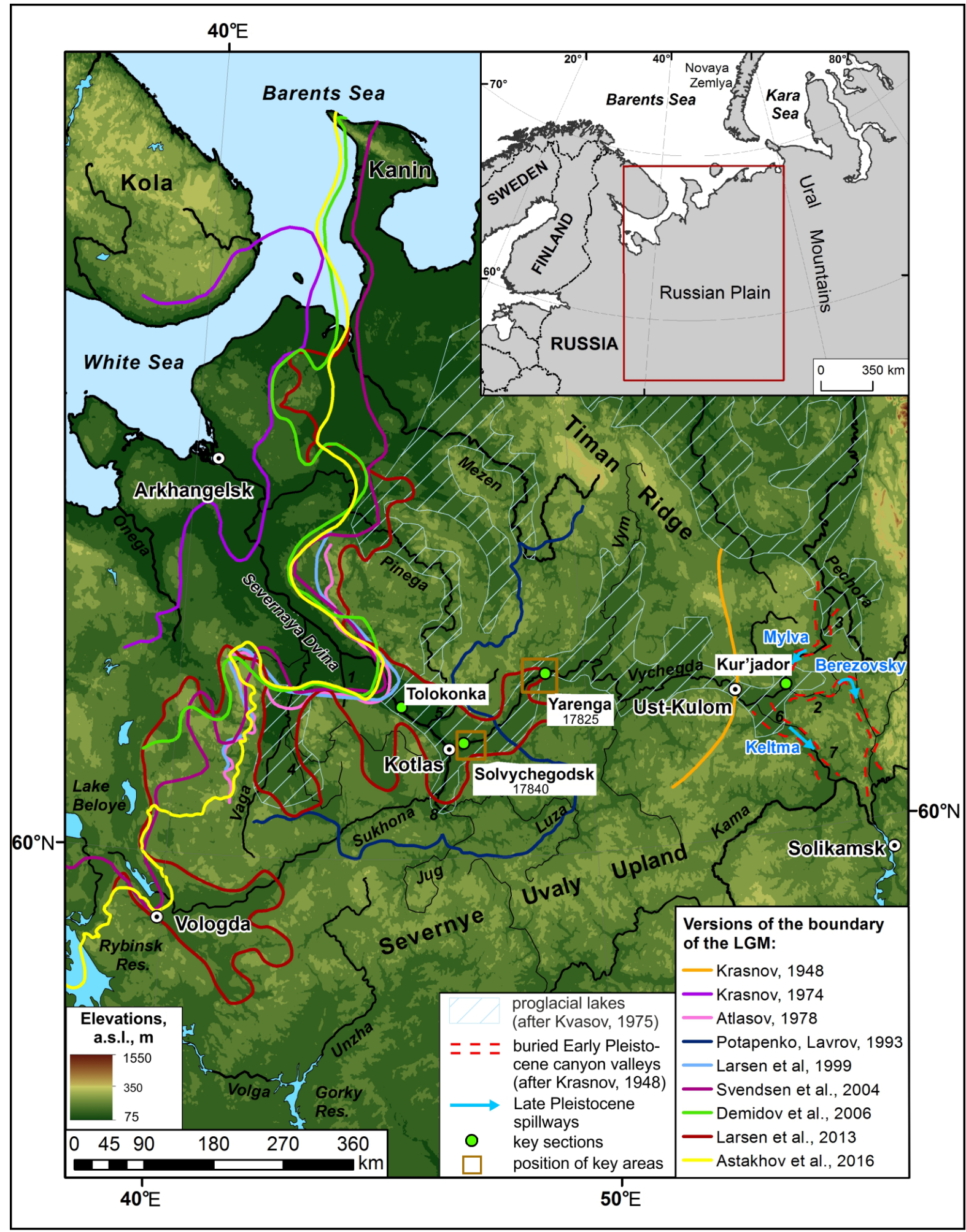

Figure 1. Overview map. 
(the Vychegda-Severnaya Dvina basin) and Southern Keltma (Kama basin). The Keltma trough is a part of the ancient system of over-deep valleys - the socalled Kama-Vychegda-Pechora drainage system, whose age was considered as pre-Quaternary ${ }^{1}$ (Krasnov, 1948). The problem of LGM proglacial lake outflow via this trough is also discussed below.

In the valleys of Vychegda, Vaga and Severnaya Dvina Rivers, a series of terraces has been formed; however, their age and genesis remains controversial.

\section{Overview of previous research of the history of ice sheets and glacially dammed lakes}

\section{1. $20^{\text {th }}$ century: accumulation of geological knowledge, first models}

Investigations of the LGM position, related icedamming phenomena and reversal runoff actively began in the 1930s and 1940s, when geological studies were conducted in the framework of the project of wide-scale reservoir construction and diversion of runoff of the northern rivers to the Caspian Basin. Krasnov (1948) considered that the maximum glaciation covering the study area occurred in the Middle Pleistocene, and positioned the glaciation center on the islands of Novaya Zemlya and the Polar Urals: petrographic composition of boulders was analyzed and correlative rocks were identified in the glacial deposits together with local ones (Krasnov, 1948). Intramoraine lenses of laminar (varve-type) clay and sands up to $5 \mathrm{~m}$ thick were encountered inside the till layer. Glaciofluvial sands and gravels covering the Kama-Pechora-Vychegda interfluve

Note that at that time, the lower Quaternary limit was recognized at the Brunnes-Matuyama boundary, 0.78 Ma BP, i.e. at the modern Lower-Middle Pleistocene boundary. were associated with the degradation of the Middle Pleistocene glaciation (Krasnov, 1948).

Meanwhile, after extensive drilling, the $5-\mathrm{km}$ wide Keltma buried canyon was discovered on the Kama-Vychegda interfluve (Fig. 1), filled with the Quaternary deposits to a depth of more than $100 \mathrm{~m}$ (Yakovlev, 1956). The canyon served as a junction between Vychegda and Kama Rivers; water from one basin could be poured into another, depending on climatic and tectonic factors (Yakovlev, 1956). No other age determinations of the uppermost canyon sediments have been done since those years.

The boundary of the last glaciation was drawn submeridionally along the western slope of the Timan ridge, then in the vicinity of Ust-Kulom (the "knee" between the submeridional current of the upper Vychegda and the sublatitudinal middle reaches) and along the watershed between the Kama and Vychegda Rivers (Fig. 1). Since the glaciation must have blocked the northward drainage, a huge proglacial basin was thought to have formed along the glacier edge due to topographic features of the area, and the runoff was directed to the south via Keltma canyon, to the Kama River valley (Fig. 1). The proglacial lake occupied the so-called Vychegda Depression (the present-day valley of the Vychegda River, part of the river valleys of Mylva and Nem). Sands and sandy loams recognized as palaeolake deposits fill the bottoms of paleodepressions and are overlain by younger alluvium. The deposition of sandy deposits rather than varved clays was explained by the possible existence of a strong current in the paleo-lake (Krasnov, 1948). Afterwards, during the 1:500000 geological mapping of the European part of the USSR, the LGM limit was moved farther to the northwest, to the North Dvina - Vaga confluence (Krasnov, 1971). The LGM-lake deposits were mapped to the lower reaches of Vychegda River (Krasnov, 1971).

The next stage in the studies of LGM boundaries developed in the 1970s due to the extensive geological survey complemented by remote sensing in the Onega-Vaga interfluve and in the valleys of Severnaya Dvina and Vaga Rivers, and the southeastern boundary of the last glaciation was 
significantly refined (Atlasov et al., 1978; Ostanin et al., 1979). The LGM boundary was shifted far to the west and acquired new, more complicated configuration (Fig. 1). Two glacier lobes were reconstructed inside the valleys of Severnaya Dvina and Vaga (Atlasov et al., 1978). Provenance studies based on the petrographic analysis of boulders collected from glacial sediments allowed a reliable distinction of the Saalian and LGM tills: the former is more abundant with local calcareous pre-Quaternary rocks, whereas in the latter, erratic Scandinavian material prevails (Ostanin et al., 1979). The glacial marginal complex composed of the hilly moraine topography with kames and glacio-fluvial hills, subglacial and glacio-fluvial ravines was mapped in detail (Atlasov et al., 1978).

The aforementioned LGM boundary reconstructions were explored by Kvasov (1975) to build the concept of wide occurrence of two deep proglacial lakes at the SIS SE boundary: Lake Vaga (Vazhskoe) occupied the lowland, enclosing the Vaga and Kokshen'ga River valleys. The drainage threshold was assumed at the watershed of Kokshenga and Uftyuga (Sukhonskaya) Rivers at the elevation of $150 \mathrm{~m}$ a.s.l.. The lake was also thought to have the reversal drainage to the Sukhona River. Varved clays of this lake are well preserved within the Vaga valley, and were observed by the author of this paper in various river sections.

Lake Kotlas (Kotlasskoe) was suggested to occupy the valley of Severnaya Dvina River (adjacent to the glacier), part of the Malaya Dvina valley (to the confluence with Luza), the Vychegda valley to the confluence with $\mathrm{Nem}$, and part of the Vym' valley (Kvasov, 1975). Reverse flow was assumed to the south into the Kama-Volga basin through the Keltma spillway, which could have been overflowed at $130 \mathrm{~m}$ a.s.l.. Nevertheless, the deposits of Kotlas Lake had not been documented and all reasoning was grounded only on landscape topography.

In the 1980s and 1990s, the next modification of the LGM boundary was presented by Lavrov \& Potapenko (2005) (Fig. 1). The authors reconstructed a single Severnaya Dvina glacier lobe, which occupied the lower reaches of Vychegda, Luza and Jug Rivers, and covered the basins of Sukhona and Vaga (Lavrov \& Potapenko, 2005). A huge Oz’jag proglacial lake with a southward drainage was interpreted to have been forming due to the glacial blockage of the Vychegda valley. The so called Oz'jag terrace was formed by glacial-lake deposits with absolute elevations of 130-135 m a.s.l., and is breaking sharply in the lower reaches of Vychegda (Potapenko, 1971). However, closer examination of the materials presented by these researchers reveals that the Oz'jag terrace was reconstructed (modelled) practically by the interpolation of the results of studies based on only one section in the Vym River basin (Lavrov \& Potapenko, 2005).

\section{2. $21^{\text {st }}$ century: revision and new models}

At the beginning of $21^{\text {st }}$ century the studies of the glacial history of Russian northern territories received a new impulse, due to international QUEEN project (Larsen et al., 1999; Svendsen et al., 2004).

The LGM map of QUEEN project in its southeastern flank mostly repeated the reconstructions made by the Russian Geological Survey (Atlasov et al., 1978; Larsen et al., 1999; Svendsen et al., 2004), but concerning the adjacent ice-dammed lakes, no certain models were proposed, except for the drainage rerouting to the Kama-Volga system. In the subsequent paper by another research group (Demidov et al., 2006) they suggested a smaller distribution of ice sheet and moved its eastern boundary westward by $20-120 \mathrm{~km}$ compared to previous reconstructions, but lowlands were still considered to have been occupied by large icedammed lakes. During LGM, the interpretations suggested an ice-dammed lake that filled the upper parts of the SD basin and reached elevations 120 $130 \mathrm{~m}$ a.s.l. with southward drainage into the Volga basin (Demidov et al., 2006). As no new evidence of LGM lake deposits or shorelines have been proposed for this area, this statement seemed simply to follow the previous reconstructions by Kvasov (1975). 
At the beginning of 2010s, a major revision of the glacial boundary in the Severnaya Dvina basin was published (Lyså et al., 2011; 2014; Larsen et al., 2013) based on glaciomorphological data extracted from satellite images (Fredin et al., 2012), and supported by the existence of glacial sediments in two sections within the SD valley downstream of Kotlas city and the valley floor moraine reconstructed within the lower reaches of the Vychegda River (Larsen et al., 2013). It was suggested that the LGM lobe pattern was much more "finger-shaped" (Fig. 1) than reconstructed in earlier works: long ice lobes with low ice-surface profiles penetrated far upstream to the gentle valleys of Vaga, Kodima, Severnaya Dvina, Vym and Vychegda Rivers (Larsen et al., 2013). In parallel, the formation of huge icedammed lakes was assumed in the valleys of all the Severnaya Dvina and Vaga tributaries based on the "lake-dominated" interpretation of sections which they studied within the river valleys. Lake levels were suggested to have reached the Keltma spill at 130-132 m a.s.l. and overflowed into the Kama basin. This point of view was shared by some Russian authors (Nazarov et al., 2015).

Our research was motivated by the above described recent revision of the LGM ice sheet boundaries and the revival of the concept of glacially dammed lake overflow into the Caspian basin. The purposes of our study are: (1) to test the evidence for the far advance of the MIS 2 ice stream along the Vychegda valley, and (2) to establish the chronology of fluvial environments at Lower Vychegda. The latter would constraint the period of Lower Vychegda occupation by the glacially dammed lake.

\section{Methods}

Field topographic survey included lithostratigraphic investigations of river sections, sampling radiocarbon and other samples from appropriate horizons, measuring terrace and section elevation above the river and producing topographic profiles with the help of 5x magnifying CB-17-630 Berger Hand Level.
Elevation maps and profiles were processed in ArcGIS 10.3.1 and Global Mapper v.19. The overview map of the study area (Fig. 1) was constructed using the digital terrain model (DTM) Gtopo2 v.2 with a resolution of $c a .1 \mathrm{~km}$ (US Geological Survey, 2015).

To study the individual sites in the Vychegda valley, three DTM were tested: ALOS World 3D30 (Japan Aerospace Exploration Agency, 2017), ArcticDEM (Polar Geospatial Center, 2017) and Tandem-X (German Aerospace Center, 2017). This was necessary because the area is characterized by non-continuous data, considerable afforestation and distortions in the altitude field observed in all DTM. Different models were used for the two study sites in the Vychegda valley.

Yarenga site in the middle lower Vychegda

\section{(section 5.1)}

The most detailed DTM is ArcticDEM (resolution $5 \mathrm{~m}$ ), but within the study area the systematic altitude distortion of about $15 \mathrm{~m}$ was revealed. Despite the lower resolution, ALOS 3D-30 (resolution $30 \mathrm{~m}$ ) proved to be best suited for the purposes of this study, because it contains fewer artefacts, and elevations demonstrate better correspondence to reference topographic maps.

\section{Solvychegodsk site at the very lower Vychegda} (section 5.2)

Using of ArcticDEM and ALOS 3D-30 was limited by holes in their cover near the section. That is why we took available tile of Tandem-X (resolution $30 \mathrm{~m}$ ) for the map and profile of the key section. In spite of a lot of artifacts and systematic altitude distortion of approximately $17 \mathrm{~m}$ that was detected and eliminated, Tandem-X was found the most adequate to reflect the main landscape features of lower Vychegda valley.

Profiles drawn from the DTM were compared with topographic maps of 1:25000-1:100000 scale. To eliminate artefacts, the profiles extracted automatically from ALOS 3D-30 and Tandem-X, were smoothed manually. 

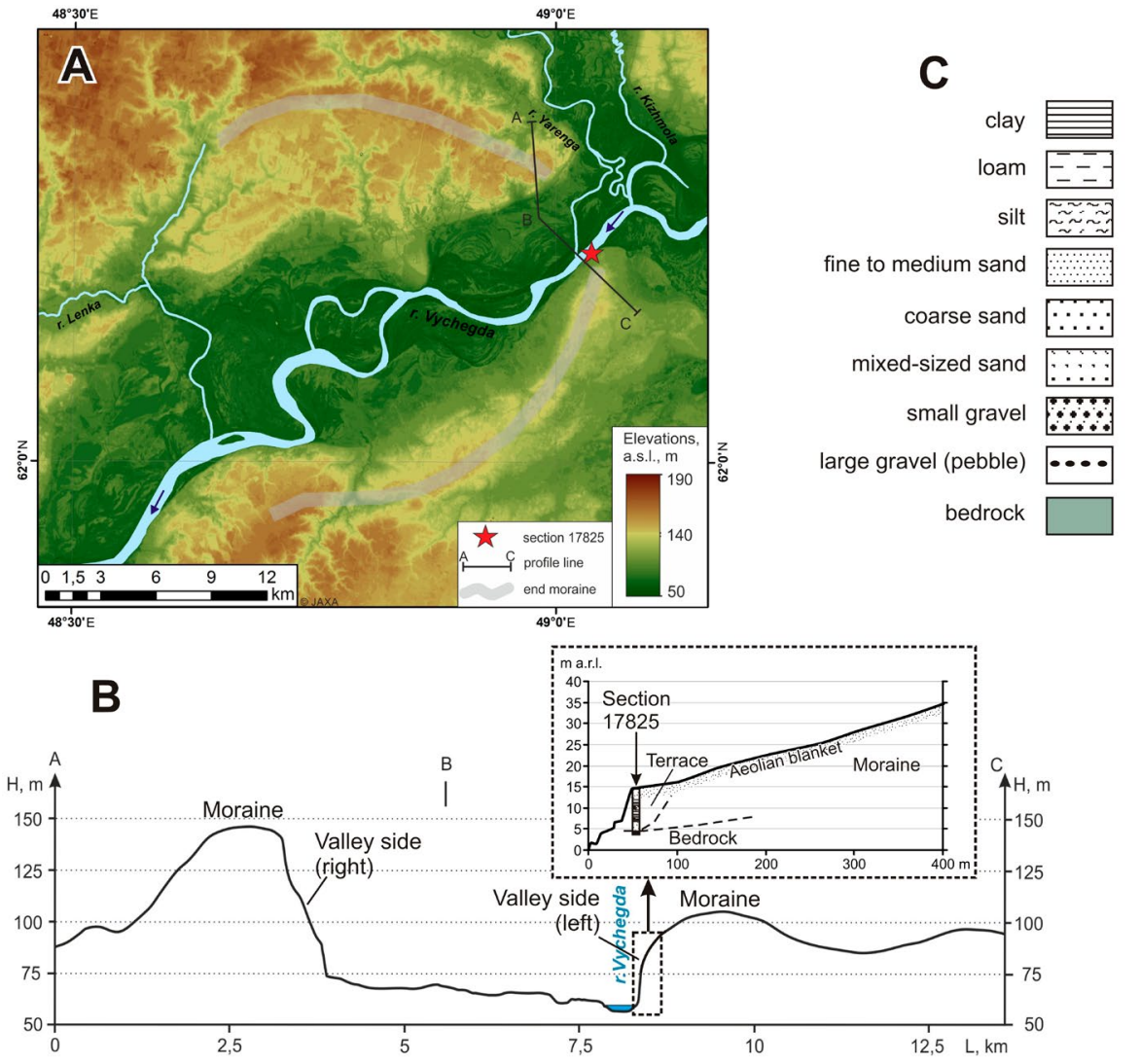

Figure 2. Vychegda valley at the Yarenga confluence. a) Topographic settings (ALOS DTM). Light grey strip outlines the arc recognized as the end moraine. b) Profile across the valley and moraine ridge (based on ALOS DTM). Inset: profile at the valley left bank (field topographic survey). c) Lithological log of section 17825 exposing the late MIS 6/MIS 5 river terrace.

\section{Results}

To meet the aims of the research, two valley reaches were studied. First is the reach at the Yarenga River confluence where Vychegda crosses the margin of the LGM ice stream proposed in Larsen et al. (2013). Second is the lowermost reach of the Vychegda valley that was studied in most detail at the Solvychegodsk town.

\subsection{Yarenga section}

At the confluence of River Yarenga, Vychegda crosses a 30-50-m high ridge having an arc planform typical for end moraines (Fig. 2a).
Apparently, it is this ridge that was interpreted by Larsen et al. (2013) as the end (valley floor) moraine of the Late Weichselian ice sheet and was used as the marker for the LGM glacial boundary and as a "dam" for the proglacial lake. However, this conclusion was based only on satellite image and DTM analysis and no data was provided on the geology and geomorphology of the Vychegda valley. This was the motivation for us to examine the valley reach at the intersection of the proposed moraine ridge.

At the Yarenga confluence, the $4.5 \mathrm{~km}$ wide valley bottom is occupied by the floodplain and low (10-13 m) terraces (Fig. 2a, b). River Vychegda undercuts the left side of the valley, which promised the chance to examine the incised moraine. 
A section 17825 located at $62.10176^{\circ} \mathrm{N}, 49.03758^{\circ} \mathrm{E}$ was cleaned down from a clear edge dividing the steep slope initially recognized as valley side and gently rising surface that extends to the top of moraine (Fig. 2B). The section 17825 consists of the following lithostratigraphic units (from top to bottom; Fig. 2c):

Unit 1 $(0.0-2.5 \mathrm{~m})$ : homogenous light-beige well-sorted fine to medium sand, iron-rich in the upper $70 \mathrm{~cm}$. Interpreted as aeolian cover.

Unit $2(2.5-3.3 \mathrm{~m})$ : horizontal interbedding of silt and fine sand; lamination is wavy horizontal in the upper $30 \mathrm{~cm}$ and plane horizontal in the rest of the unit. Interpretation: overbank alluvia.

Unit 3 $(3.3-10.1 \mathrm{~m})$ : mixed-sized sands with horizontal beds and lenses of sandy gravels and loams and rare pebble-rich layers; below $7.4 \mathrm{~m}$ - fine sand with rare pebbles in the top part. Interpretation: channel alluvia.

Unit 4 (below $10.1 \mathrm{~m}$ ): bluish grey clay intercalated with sandy clay. Interpretation: bedrock (Jurassic marine rock).

Below the bottom of the section, there are a couple of terraces produced by landsliding of the bedrock clays. Young floodplain 1-1.5 m high makes a narrow $(5-7 \mathrm{~m})$ strip at the bank of the river.

\subsection{Solvychegodsk Section}

Section 17840 was examined on the right bank of Vychegda, $20 \mathrm{~km}$ upstream from it's confluence with the Severnaya Dvina River, at the Solvychegodsk town. The left bank of Vychegda is formed by a 2-4 $\mathrm{m}$ high floodplain and the right bank is the 6-8 $\mathrm{m}$ high river terrace that bears numerous traces of river palaeochannels (Fig. 3a, b). The section 17840 is located within the migration belt of the oldest meander generation that was abandoned not later than 9260 70 BP (Panin et al., 1999). Petikhino Lake (Fig. 3b) is located within one of the palaeochannels belonging to this system. Northwards from the lake, the higher terrace is located, the surface of which gradually rises towards the right side of the valley from $12-15 \mathrm{~m}$ to more than $20 \mathrm{~m}$ above the river. This is the so called Baika terrace studied on the left bank of Vychegda (Panin et al., 1999; Sidorchuk et al., 2001) and recognized as the potential lacustrine terrace related to the LGM ice-dammed lake (Sidorchuk et al., 1999). Therefore the Solvychegodsk section describes the composition of the oldest preserved generation of fluvial landforms produced by Vychegda after the drainage of the glacier-dammed lake and incision into the lake bottom.

The section 17840 consists of three main lithostratigraphic units (from top to bottom; Fig. 3c):

Unit $1(0.0-1.1 \mathrm{~m})$ : presumably sands, subdivided into two parts based on the presence of organic-rich beds.

Subunit 1a: interchange of light-grey compact silts with thin horizontal bedding at places, and light-beige fine sand with massive texture or unclear horizontal beds. In the lower $10 \mathrm{~cm}$ sand is interlaid with thin peaty and silty beds.

Subunit $1 b$ : fine sand with thin peaty beds and two horizons of brown peat. The $12-18 \mathrm{~cm}$ thick upper peat contains thin beds and lenses of fine sand. The lower peat is broken by frost action into wedge-like structures. It was radiocarbon dated to $10050 \pm 40 \mathrm{BP}$ (GIN-15704) or $11570 \pm 120$ cal BP. Both peat horizons draw together in the downstream direction so that in the right wall of the section the dividing peaty sand between them has a thickness of less than $5 \mathrm{~cm}$.

Unit $2(1.1-1.95 \mathrm{~m})$ : horizontal interbedding of bluish-grey silty loam and greyish-beige loamy fine sand. Interpretation: overbank alluvial deposits.

Unit $3(1.95-6.2 \mathrm{~m})$ : presumably sands, subdivided into three parts based on textural properties.

Subunit 3a $(1.95-4.1 \mathrm{~m})$ : fine light-grey or yellowish-grey sand with ripple structures marked by organic-rich laminas in the upper part, horizontal bedding in the middle and large-amplitude (ca. $1.5 \mathrm{~m})$ cross-bedding in the lower part.

Subunit 3b (4.1-4.7 m): interbedding of gently sloping light-grey fine sand and bluish-grey silty loam. Wooden twig in the top of the layer was radiocarbon dated to $11290 \pm 70$ BP (GIN-15706) or $13160 \pm 60 \mathrm{cal} \mathrm{BP}$. 

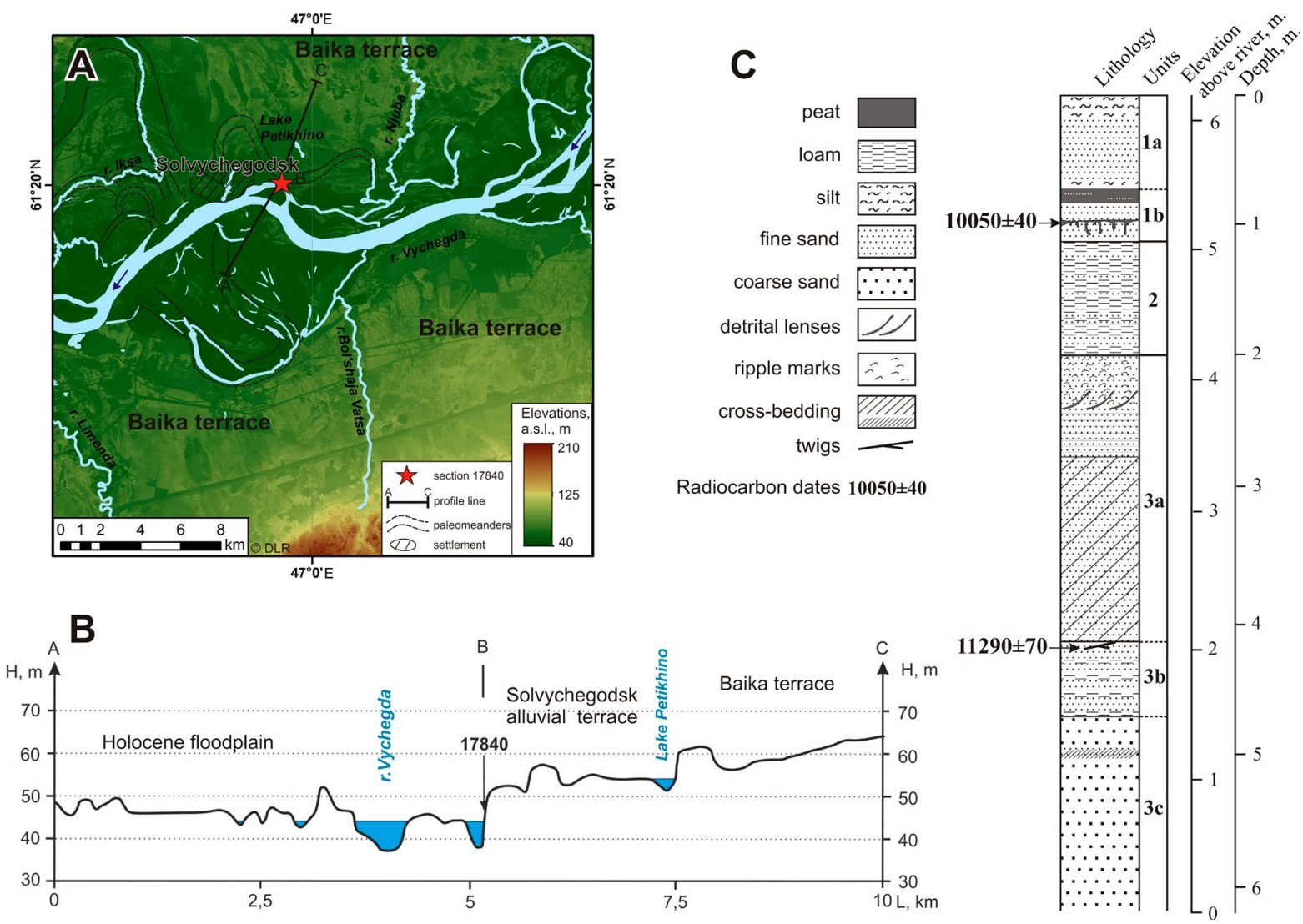

Figure 3. Vychegda valley at Solvychegodsk. a) Topographic settings (Tandem-X DTM). Dashed lines mark river palaeochannels (after Panin et al., 1999). b) Topographic profile across the valley and moraine ridge (based on Tandem-X DTM). c) Lithological log of section 17840 exposing the 6-m river terrace.

Subunit 3c (4.7-6.2 m, bottom of the section): coarse sand with horizontal or gently sloping lamination and lenses or $1-\mathrm{cm}$ thick layers of fine sand. At depth 4.97-5.1 m- layer of fine sand with cross bedding.

The section was interpreted to document a full alluvial sequence accumulated on a convex bank of a river meander: active channel alluvia (Subunit 3c), organic-rich deposits of a pool in the backside of a point bar (Subunit 3b), point bar alluvia (Subunit 3a) and overbank alluvia (Unit 2). The uppermost unit was interpreted as aeolian sand drifted over a bog in its lower part (Subunit 1b). The sand cover continues far outside the river into the second terrace.

\section{Discussion and conclusions}

Since the beginning of $21^{\text {st }}$ century, the arguments were proposed in favour of the limited distribution of the LGM proglacial lake in the Vychegda valley (Sidorchuk et al., 2001) and in the middle reaches of the Northern Dvina (Zaretskaya et al., 2014; Maksimov et al., 2015). Since 2011 we provided studies of terraces composing the intra-valley fluvial complex of Vychegda, tracing them from the upper reaches (Severnaya Keltma valley) to river mouth near Kotlas city. The composition of the Late Pleistocene terraces is twofold: the lower (bottom) part is usually composed of alluvium (sands, sandy gravels and pebbles, loams and sometimes peat or loamy peat of oxbow lake deposits); the 
upper part is usually formed by deposits of aeolian origin: in the upper reaches of the river these are silts presumably of niveo-aeolian genesis (for example, at the Kur'jador section, Maksimov et al., 2015; Andreicheva et al., 2015) blanketing the surrounding landforms, but in most part of the valley these are sands without grading with dunes on the surface (Zaretskaya et al., in press). The Late Glacial terraces demonstrate the same composition: the age of their alluvial bottom parts varies between 17 and 12 cal kyr BP (Zaretskaya et al., 2014), and no varved clays have been identified.

The Yarenga reach of the Vychegda valley (Fig. 2a) is a key for understanding the glacial limits at Lower Vychegda. There are several arguments for rather MIS 6 than MIS 2 age of the arc-shaped endmoraine ridge crossed by Vychegda.

First is the existence of more than $13 \mathrm{~m}$ high river terrace exposed in the section 17825, the age of which is evidently older than LGM. This interpretation follows from a number of terrace parameters. The base of terrace alluvia lays $5 \mathrm{~m}$ above the river (Fig. 2c). In Lower and Middle Vychegda this is characteristic for MIS 6/5 terraces formed at the initial stages of river restoration after the MIS 6 ice sheet retreat, whereas all dated MIS 2 terraces are composed totally of alluvium in their above-river parts and have elevations mostly below $10 \mathrm{~m}$ (Zaretskaya et al., 2014; Zaretskaya et al., in press). Terrace alluvia is devoid of organic matter suitable for radiocarbon dating, which is not typical for the MIS 2 terraces that are usually rich in peat layers and other organic remains. Also, the terrace at the section 17825 is covered by sand blanket (Unit 1), which was traced in the field as far as $0.5 \mathrm{~km}$ upslope from the section (Fig. 2c). Examination of satellite images showed that these sands cover the whole moraine ridge, which supports the lithological arguments on the aeolian origin of Unit 1. Lavrov and Potapenko (2005) map these sands as the MIS 2 glacio-lacustrine deposits. However, we have not found any evidence of aquatic sedimentation: mostly massive structure, high degree of sorting and absence of noticeable amounts of clay-silt fraction stands for their aeolian origin, probably related to the activation of wind-blowing processes from the water-deficient valley in LGM.

Another reasoning for the pre-LGM age of the Yarenga moraine ridge relates to the high density of erosional dissection of the ridge, which is evident in the area topography (Fig. 2a). Drainage net that covers the sides of the moraine on both sides of the Vychegda valley is quite typical for the territory to the east, which was undoubtedly occupied last time by the MIS 6 ice sheet. Territories north from the Tolokonka section on Northern Dvina that were covered by SIS at LGM are eroded to much less extent.

Given the above reasoning, we argue that the end moraine crossed by Vychegda at the Yarenga site was formed during the MIS 6 glaciation and cannot be used as an evidence of the glacial advance at the LGM. As a consequence, the blockage for the proposed LGM lake (Larsen et al., 2013) could not have existed in the middle Vychegda valley, and we failed to detect any traces of such lake in this part of the valley, which provides no ground for the concept of water overflow into the Kama River (Caspian basin) through the Keltma pass in the upper Vychegda basin.

Traces of river damming related to the last glaciation were detected earlier in the lower Vychegda. The more than $12 \mathrm{~m}$ thick terrace on the right bank at Solvyshegodsk (Fig. 3) is most probably the same terrace that was described on the left bank at the Baika village (Sidorchuk et al., 1999; 2001). The alluvial-lacustrine base of the terrace was radiocarbon dated to $c a$. 45-50 ka BP (Zaretskaya et al., in press). The upper part of the sequence was described as sand accumulated most probably in deltaic environment generated by base level rise due to river damming somewhere downstream. This terrace was traced $50-70 \mathrm{~km}$ upstream, its relative elevation decreases, and finally the Baika terrace merges with the 6-8 $\mathrm{m}$ thick Late Glacial terrace (Sidorchuk et al., 1999). 
Given the above reasoning, the composition of the Baika terrace and its position within the valley prove the occurrence of the LGM glacially dammed lake in the Severnaya Dvina valley only. The chronology of the lake drainage is still unknown as the Baika terrace was not dated because of the absence of organic material in the upper alluvial/deltaic sands. The lake drainage could be constrained by the age of the subsequent fluvial complexes. Earlier, the oldest river palaeochannels were dated at $9.3{ }^{14} \mathrm{C}$ ka BP, or $c a .10 .5 \mathrm{cal} \mathrm{ka} \mathrm{BP}$ (Panin et al., 1999; Sidorchuk et al., 1999), which gives a rather obvious conclusion that the incision into the Baika terrace started already before the beginning of the Holocene.

The section 17840 at Solvychegodsk allows us to conclude that the Vychegda incision into the Baika terrace caused by the drainage of lake in the Severnaya Dvina valley had started already before the Allerød. Section composition demonstrates that at 13.0-13.2 cal ka BP, the water surface of the river was at least $2 \mathrm{~m}$ above the present-day river (top of the pool deposits of Subunit 3b). Due to the continued incision, the flooding of the Solvychegodsk terrace ceased in less than 1500 years (by $11.5 \mathrm{cal} \mathrm{ka} \mathrm{BP}$ ), which is marked by the start of aeolian sedimentation over the overbank alluvia (Fig. 3c).

According to the elevation of dated terrace/ floodplain steps synthesized in (Panin et al., 1999), incision ceased around $7-8{ }^{14} \mathrm{C} \mathrm{ka} \mathrm{BP}$, or $8-9 \mathrm{cal}$ ka BP. Extrapolation of incision rates $(2 \mathrm{~m}$ per 4000-5000 years) provides the estimation of the start of incision into the Baika terrace (ca. $6 \mathrm{~m}$ above the Solvychegodsk terrace) at 25-30 ka BP. Most probably, this estimate is too old as the incision must have slowed down in time, and the initial phase (before the formation of the Solvychegodsk terrace) was much faster than the terminal phase. Indirectly, fast initial incision into the Baika terrace is indicated by the absence of morphologically expressed meandering belts. To more reliably establish the chronology of lake drainage/start of Vychegda incision, direct dating of the Baika terrace material is necessary, and is now included in our projects. However, whatever the result, it would not abolish the overall conclusion about the absence of the dammed lake in the Vychegda valley at LGM and, in addition, the absence of its overflow through the Arctic-Caspian watershed.

\section{Acknowledgements}

Field investigations of alluvial section stratigraphy, studies of the LGM glacial boundary and traces of glacial damming are supported by Russian Science Foundation (RSF), project no. 17-17-01289. Financial support for geochronological studies (radiocarbon dating) was received from the Russian Foundation for Basic Research (RFBR), project no. 17-05-00706. To construct DTMs, we used a number of sources: ALOS data operated by the JAXA, Gtopo data available from the U.S. Geological Survey, ArcticDEM data, created from Digital Globe, Inc., imagery 2012-2016, and provided by the Polar Geospatial Center under NSF OPP awards 1043681, 1559691 and 1542736, and TanDEM-X data that was kindly provided by the German Aerospace Center (DLR) within the proposal ID: DEM_GEOL1527. Authors are grateful to two anonymous reviewers for valuable comments on the manuscript. 


\section{References}

Andreicheva L.N., Marchenko-Vagapova T.I., Buravskaya M.N. \& Golubeva Yu.V., 2015. Prirodnaya sreda neopleistocena I golocena na evropeiskom severo-vostoke (Palaeoenvironment of the Neopleistocene-Holocene in the European Northeast). Moscow, GEOS, 223 p. (in Russian).

Atlasov, R.R., Bukreev, V.A., Levina, N.B. \& Ostanin, V.E., 1978. Relief peculiarities of terminal zone of Valdai glaciation on Onega-Vaga waterdivide and in Vaga valley. In: Kraevye obrazovania materikovych oledeneniy (Terminal formation of continental glaciations). Kiev, Naukova Dumka, pp. 30-38 (in Russian).

Demidov, I.N., Houmark-Nielsen, M., Kjær, K.H. \& Larsen, E., 2006. The last Scandinavian Ice Sheet in northwestern Russia: ice flow patterns and decay dynamics. Boreas 35, 425-443. https://doi.org/10.1080/03009480600781883

Fredin O., Rubensdotter L., van Welden A., Larsen E. \& Lyså A., 2012. Distribution of ice marginal moraines in NW Russia. Journal of Maps 8, 236-241. https://doi.org/10.1080/17445647.2012.708536

German Aerospace Center (DLR). Page last updated: 2017 year. Available online: https://tandemx-science.dlr.de/ (accessed on 14 March 2018).

Gibbard, P. \& Cohen K.M., 2008. Global chronostratigraphical correlation table for the last 2.7 million years. Episodes 31, 243-247.

Japan Aerospace Exploration Agency. Page last updated: March 2017. Available online: http://www.eorc.jaxa.jp/ALOS/en/aw3d30/index.htm (accessed on 14 March 2018)

Krasnov, I.I., 1948. Quaternary deposits and geomorphology of the Kama-Pechora-Vychegda interfluve and adjacent areas (Chetvertichnye otlozheniya i geomorfologiya Kamsko-Pechorsko-Vychegodskogo vodorazdela i prilegayuschikh territoriy). Materialy po geomorfologii Urala, Issue 1, pp. 47-88 (in Russian).

Krasnov, I.I. (Ed.), 1971. Map of the Quaternary deposits of the European part of the USSR. Scale 1:1 500000 (Karta chetvertichnyh otlozhenii Evropeiskoi chasti SSSR). Leningrad, VSEGEI, 16 sheets (in Russian).

Kvasov, D.D., 1975. Late Pleistocene history of large lakes and inner seas of Eastern Europe (Pozdnechetvertichnaya istoria krupnykh ozer I vnutrennikh morei Vostochnoi Evropy). Leningrad, Nauka, 278 p. (in Russian).

Larsen, E., Lyså, A., Demidov, I.N., Funder, S., HoumarkNielsen, M., Kjær, K.H. \& Murray, A.S., 1999. Age and extent of the Scandinavian ice sheet in northwest Russia. Boreas 28, 115-132.

https://doi.org/10.1111/j.1502-3885.1999.tb00209.x
Larsen, E., Fredin, O., Jensen, M., Kuznetsov, D., Lyså A. \& Subetto, D., 2013. Subglacial sediment, proglacial lakelevel and topographic controls on ice extent and lobe geometries during the Last Glacial Maximum in NW Russia. Quaternary Science Reviews, 92, 369-387. https://doi.org/10.1016/j.quascirev.2013.02.018

Lavrov, A.S. \& Potapenko, L.M., 2005. Neopleistocene of the North-East of the Russian plain (Neopleistocen SeveroVostoka Russkoi ravniny). Moscow, Aerogeologiya, 348 p. (in Russian).

Lisiecki, L. E., \& Raymo, M. E., 2005. A Pliocene-Pleistocene stack of 57 globally distributed benthic $\delta^{18} \mathrm{O}$ records. Paleoceanography 20, PA1003.

https://doi.org/10.1029/2005PA001164

Lyså, A., Jensen, M.A., Larsen, E., Fredin, O. \& Demidov, I.N., 2011. Ice-distal landscape and sediment signatures evidencing damming and drainage of large pro-glacial lakes, northwest Russia. Boreas 40, 481-497. https://doi.org/10.1111/j.1502-3885.2010.00197.x

Lyså, A., Larsen, E., Buylaert, J.-P., Fredin, O., Jensen, M., Kuznetsov, D., Murray, A.S., Subetto, D.A. \& Van Welden A., 2014. Late Pleistocene stratigraphy and sedimentary environments of the Severnaya DvinaVychegda region in northwestern Russia. Boreas 43, 759-779. https://doi.org/10.1111/bor. 12080

Maksimov, F. E., Zaretskaya, N. E., Shebotinov, V. V., Kuznetsov, V. Yu., Uspenskaya, O. N., Grigoryev, V. A. \& Kuksa K. A., 2015. A new approach to isotope dating of buried organic-rich deposits with an example from the Kuryador section, upper Vychegda valley. Doklady Earth Sciences 462, 570-574. https://doi.org/10.1134/S1028334X15060185.

Nazarov, N.N., Chernov, A.V. \& Kopytov, S.V. Restructuration of Northern Sis-Ural drainage network in the Late Pleistocene and Holocene (Perestroiki rechnoi seti Severnogo Preduralia v pozdneem pleisotcene i glocene). Gograficheskii vestnik 3:34, 26-34 (in Russian).

Ostanin, V.Ye., Atlasov, R.R., Bucreyev, V.A. \& Levina, N.B., 1979. Terminal Formations and Valdaian Glaciation Limit in the Vaga River Basin (Kraevye obrazovania I granitsa valdaiskogo oledenina $\mathrm{v}$ basseine $\mathrm{r}$. Vagi). Geomorphologiya 1, 72-76 (in Russian).

Panin, A.V., Sidorchuk, A.Ju. \& Chernov, A.V., 1999. Historical background to floodplain morphology: examples from the East European Plain. In: Marriott, S., Alexander, J. \& Hey, R. (eds.), Floodplains: Interdisciplinary Approaches. Geological Society, London, Special Publications 163, pp. 217-229. https://doi.org/10.1144/gsl.sp.1999.163.01.17 
Polar Geospatial Center. Page last updated: September 2017. Available online: https://www.pgc.umn.edu/guides/ arcticdem/introduction-to-arcticdem/ (accessed on 14 March 2018)

Potapenko, L.M., 1971. Structure and formation of the terraces of the Vychegda river basin (Stroenie I uslovia formirovania terras basseina r. Vychegdy). Vestnik Moskovskogo Universiteta, Seria 5, Geografia 3, 97-104 (in Russian).

Sidorchuk, A., Borisova O., Kovalyukh N. \& Panin A., 1999. Palaeohydrology of the lower Vychegda River in the Late Glacial and Holocene (Paleogidrologia nizhnei Vychegdy v pozdnelednikovie i golocene). Vestnik Moskovskogo Universiteta, Seria 5, Geografia 5, 34-41 (in Russian).

Sidorchuk, A., Panin A., Borisova O. \& Kovalyukh N., 2001. Lateglacial and Holocene palaeohydrology of the lower Vychegda river, western Russia. In: Maddy, D., Macklin, M.G. \& Woodward, J.C. (eds.), River Basin Sediment Systems: Archives of Environmental Change. A.A.Balkema Publishers, pp. 265-295. https://doi.org/10.1201/9781439824672.ch9

Svendsen, J. I., Alexanderson, H., Astakhov V. I. et al., 2004. Late Quaternary ice sheet history of Northern Eurasia. Quaternary Science Reviews 23, 1229-1271. https://doi.org/10.1016/j.quascirev.2003.12.008
U.S. Geological Survey. Page last updated: January 2015. Available online: https://la.cr.usgs.gov/GTOPO30 (accessed on 14 March 2018)

Velichko, A.A., Faustova, M.A., Pisareva, V.V., Gribchenko, Yu.N., Sudakova, N.G. \& Lavrentiev, N.V., 2011. Glaciations of the East European Plain: Distribution and Chronology. In: Ehlers J., Gibbard P.L. \& Hughes P.D (eds.), Quaternary Glaciations - Extent and Chronology, A Closer Look. Elsevier, Amsterdam, pp. 337-359. https://doi.org/10.1016/b978-0-444-53447-7.00026-x

Yakovlev, S.A., 1956. Basic principles of Quaternary geology of the Russian Plain (Osnovy geologii chetvertichnyh otlozheniy Russkoi ravniny). VSEGEI, New series, v. 17, $315 \mathrm{p}$.

Zaretskaya, N. E., Panin, A. V., Golubeva, Yu. V. \& Chernov A. V., 2014. Sedimentation Settings and the Late Pleistocene-Holocene: Geochronology in the Vychegda River Valley. Doklady Earth Sciences 455, 223-228. https://doi.org/10.1134/S1028334X14030118

Zaretskaya, N.E., Korsakova, O.P. \& Panin, A.V., in press. MIS 3 on the European Northeast: geochronology and events. Russian Geology and Geophysics. 